\title{
THE DURATION OF NORMAL HEART SOUNDS
}

BY

\author{
ALDO A. LUISADA, FELIPE MENDOZA,* AND \\ MARIANO M. ALIMURUNG $\dagger$
}

From Tufts College Medical School, Boston, Mass.

Received July 30, 1948

The gradually increasing importance of phonocardiography creates problems that at times are difficult to solve-among them, that of deciding whether the complexes revealed by a tracing are still within normal limits. Therefore, knowledge of exact normal data is of interest as a basis for the study of clinical tracings.

Many authors studied the normal heart sounds between 1907 and 1937. Their data have been reviewed and can be found in a comprehensive work by Rappaport and Sprague (1942). As, however, those studies were made by means of various techniques, any comparison with our data is impossible and their detailed quotation needless.

The only article that dealt with the same problem and used a similar technique is by Rappaport and Sprague (1942). Our study was made by means of the stethoscopic microphone; therefore, reference will be made only to data obtained by those authors using this microphone.

Rappaport and Sprague studied 33 normal persons between the ages of 19 and 38, and gave the maximal and minimal duration of the heart sounds recorded at the apex (Table I). No average data were given by them.

While these data àre extremely useful, they are not sufficient for clinical studies because (a) they refer to only one age group, (b) they give only the total duration without breaking down the sounds into their various phases, and (c) no average figures are given. For these reasons, an additional, more comprehensive study was considered necessary.

The Main Phases of the Cardiac Sounds

As known, the first and second sounds are actually " noises," consisting of various vibrations having different frequencies. Both the first and the second sounds are caused by four different factors. Four different components were, therefore, described in both the first (Orias and Braun Menendez, 1939) and second sounds. (Rappaport and Sprague, 1941 and 1942)

The systematic clinical use of phonocardiography convinced one of us (Luisada) of the extreme variability of the complexes of the heart sounds even in normal subjects. In many of these, separation of the complexes into four components is impossible. On the other hand, the occasional observation of cases where the large vibrations of either the first or the second sound are far more numerous than in the average tracing forces one to know not only the overall duration of the sounds but also the duration of their individual components. For this reason, while we fully recognize the accuracy

TABLE I

Data of RAPPaport and SPRAGUe

\begin{tabular}{|c|c|c|c|c|c|}
\hline & & $\begin{array}{l}\text { First sound } \\
\quad(\mathrm{sec} .)\end{array}$ & $\begin{array}{l}\text { Second sound } \\
(\mathrm{sec} .)\end{array}$ & $\begin{array}{l}\text { Third sound } \\
\text { (sec.) }\end{array}$ & $\begin{array}{l}\text { Interval II-III } \\
(\text { sec.) }\end{array}$ \\
\hline $\begin{array}{l}\text { Maximum duration } \\
\text { Minimum duration }\end{array}$ & $\begin{array}{lll}. & . & . \\
. & . & .\end{array}$ & $\begin{array}{l}0 \cdot 165 \\
0 \cdot 105\end{array}$ & $\begin{array}{l}0 \cdot 145 \\
0.085\end{array}$ & $\begin{array}{l}0.085 \\
0.030\end{array}$ & $\begin{array}{l}0 \cdot 240 \\
0 \cdot 160\end{array}$ \\
\hline
\end{tabular}

* Member of the Instituto Nacional de Cardiologia de Mexico. $\dagger$ Dept. of Medicine, Faculty of Medicine, Santo Tomas University, Manila, Philippines. 
and the theoretical importance of dividing the sound complexes into many components, we think that a simplified system of study may have practical value. The following description is based on purely practical considerations.

In both the first and second sounds, the main part of the complex consists of large irregular vibrations, caused in the main by valvular events, while the beginning and the end of the sound is formed by slower vibrations. Therefore, division of each sound into three phases is relatively easy (Fig. 1).

Tables II and III show the causes of these phases and correlate them with the various components of each sound.

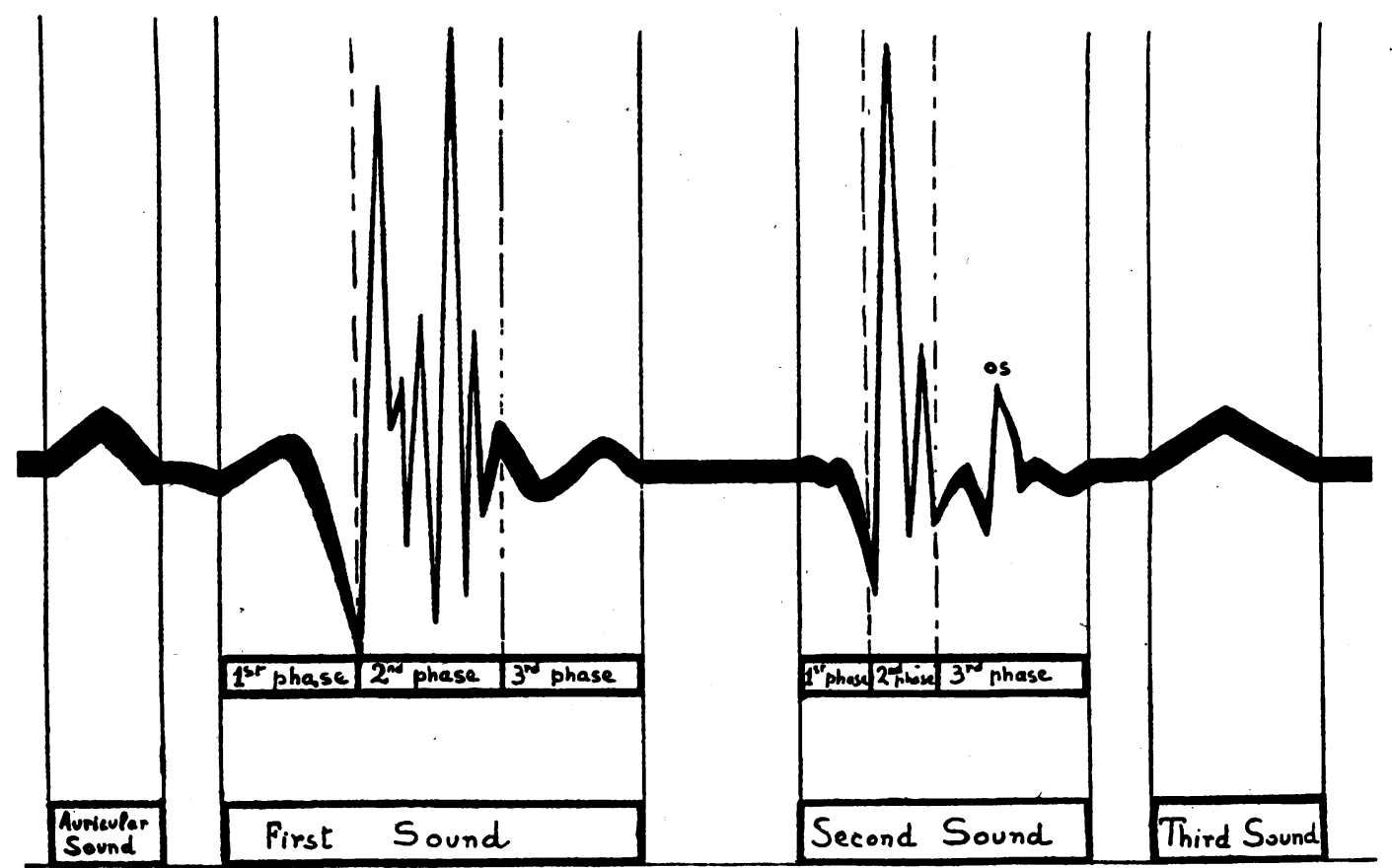

FIG. 1.-Diagram of a normal phonocardiogram recorded with a stethoscopic microphone. Practical division of the first and second sounds into three main phases.

TABLE II

Causal and Practical Division of the First Sound Complex

\begin{tabular}{|c|c|c|c|}
\hline Component & Cause & Type of vibration & Phase (new terminology) \\
\hline 1st & Auricular residual vibrations & 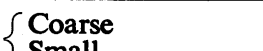 & \\
\hline 2nd & $\begin{array}{l}\text { Vibrations due to the isometric contrac- } \\
\text { tion of the ventricles }\end{array}$ & $\left\{\begin{array}{l}\text { Small } \\
\text { Coarse } \\
\text { Small }\end{array}\right.$ & $\begin{array}{l}\text { t phase, o } \\
\text { initial vit }\end{array}$ \\
\hline 3 rd & $\begin{array}{l}\text { Vibrations due to the closure of the A-V } \\
\text { valves }\end{array}$ & $\left\{\begin{array}{l}\text { Fine } \\
\text { Large }\end{array}\right.$ & 2nd phase or phase of the fine \\
\hline 4th & $\begin{array}{l}\text { Vibrations due to the opening of the semi- } \\
\text { lunar valves. }\end{array}$ & $\left\{\begin{array}{l}\text { Fine } \\
\text { Large }\end{array}\right.$ & large vibrations \\
\hline 5th & $\begin{array}{l}\text { Vibrations due to the ejection of blood } \\
\text { and to arterial distention }\end{array}$ & $\left\{\begin{array}{l}\text { Coarse } \\
\text { Small }\end{array}\right.$ & $\begin{array}{l}\text { 3rd phase, or phase of the coarse, } \\
\text { final vibrations }\end{array}$ \\
\hline
\end{tabular}

As will be noted, our division into components of the first sound is slightly different from that of Orias and Braun Menendez (1939) for the following reasons.

(a) The muscular factor gives vibrations that may be superimposed on all the others. On the other hand, a slow vibration frequently initiates the first sound in cases of complete A-V block or auricular fibrillation. This is due to the isometric contraction ventricles. It is difficult to say whether the muscle itself is causing it or whether it is due to initial vibrations of the mitral and tricuspid valves preceding their closure.

(b) The valvular factor gives vibrations that 
TABLE III

Causal and Practical Division of the Second Sound Complex

\begin{tabular}{|c|c|c|c|}
\hline Component & Cause & Type of vibrations & Phase (new terminology) \\
\hline $\begin{array}{l}\text { 1st } \\
\text { 2nd } \\
\text { 3rd } \\
4 \text { th }\end{array}$ & $\begin{array}{l}\text { Vibrations preceding the closing of the } \\
\text { semilunar valves } \\
\text { Vibrations caused by the closure of the } \\
\text { semilunar valves } \\
\text { Arterial vibrations } \\
\text { Vibrations due to the opening of the A-V } \\
\text { valves }\end{array}$ & $\left\{\begin{array}{l}\text { Coarse } \\
\text { Small } \\
\text { Fine } \\
\text { Large } \\
\text { Fine or coarse } \\
\text { Small } \\
\text { May be fine } \\
\text { Usually coarse and } \\
\text { small }\end{array}\right.$ & 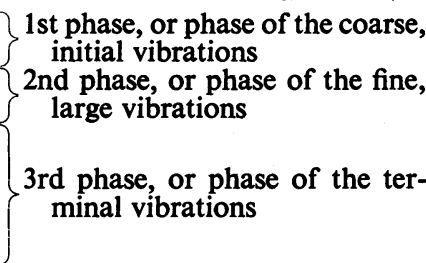 \\
\hline
\end{tabular}

often are clearly separated (Fig. 2 and 3) and may even cause an audible splitting of the sound. Both $A-V$ valve closure and semilunar valve opening are accompanied by rapid large vibrations. The latter are clearly separated from the following vibrations of vascular origin.

On the contrary, the theoretical division of the second sound into four components, as made by Rappaport and Sprague, is exact and should not be changed. It should be pointed out, however, that the vibration due to the opening of the mitral valve may become audible even in normal subjects and 'give a high wave on the tracings, as reported by one of us (Luisada, 1943 and 1948) and shown by Fig. 4.

\section{Results of THE StUdY}

Our study was based on the private collection of one of us (Luisada), consisting of over 1500 phonocardiograms. Cases with a clinical diagnosis of heart disease, an abnormal electrocardiogram, or a recorded murmur were excluded. This left 185 cases which, grouped by age, were divided as follows:

(a) 4 cases of fotal sounds recorded during various stages of pregnancy.

(b) 1 case below 4 years of age.

(c) 2 cases between 4 and 10 years of age.

(d) 7 cases between 11 and 20 years of age.

(c) 56 cases between 21 and 40 years of age.

(f) 38 cases between 41 and 60 years of age.

(g) 17 cases above 60 years of age.

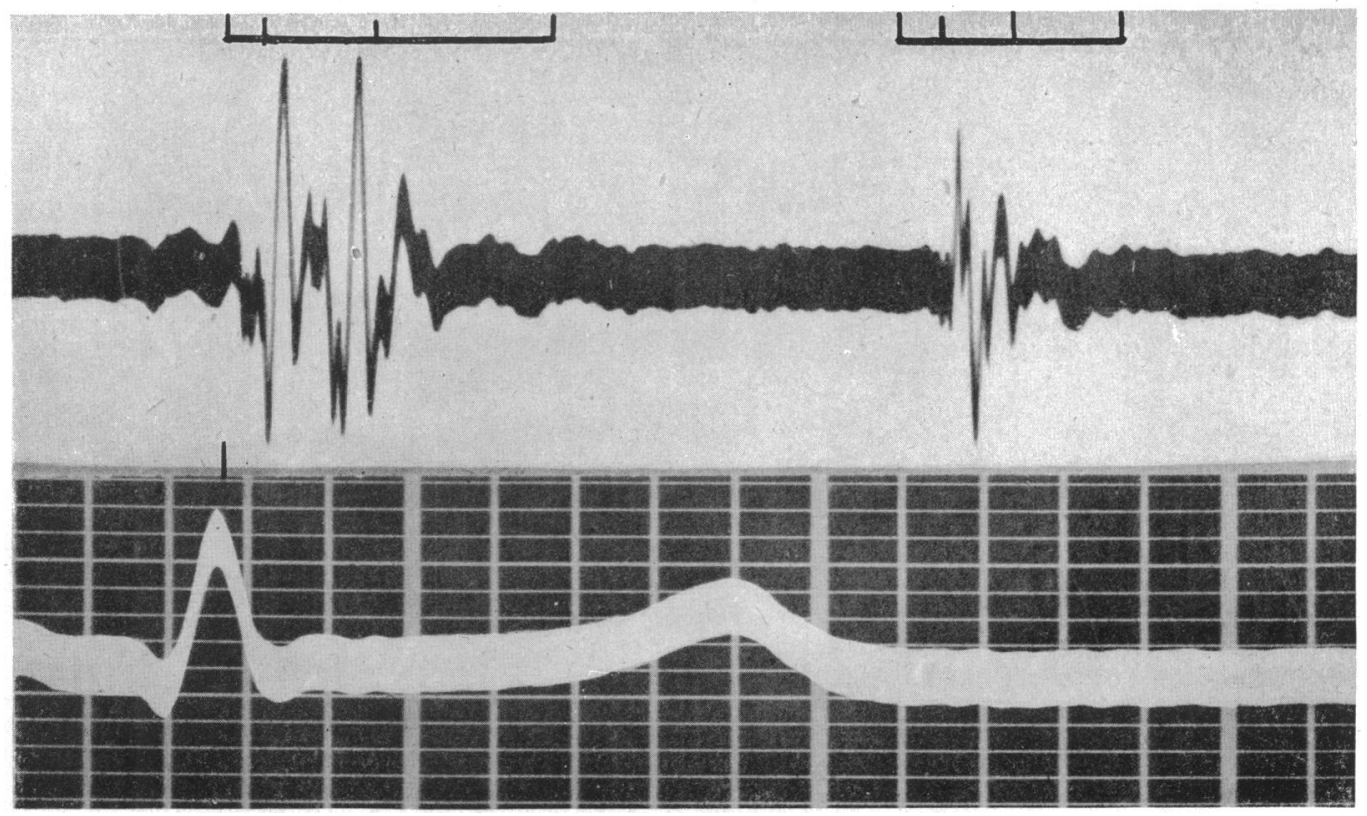

Fig. 2.-Phonocardiogram of a normal subject, aged 24 years. The first sound presents two higher vibrations in phase 2 . 
On account of the small number below 10 years of age, the average figures were made only for those above that age. In each case, the study was made on phonocardiograms recorded by means of a Stetho-cardiette and a stethoscopic microphone with a large funnel *; only tracings recorded at the apex (181 cases) and at the aortic area (73 cases) were considered (fœtal sounds excepted).

The data that were measured were as follows.

(1) Duration of the auricular sound from beginning to end.

(2) Total duration of the first sound, from the beginning of the coarse initial deflection to the end of the last coarse vibration of vascular origin. $\dagger$

(3) Partial durations of the three phases of the first sound (coarse initial vibrations, high and fine central vibrations, and coarse final vibrations).

(4) Total duration of the second sound, from the beginning of the coarse, initial vibrations to the end of the coarse final vibrations.

(5) Partial duration of the three phases of the second sound (coarse initial vibrations, high and fine central vibrations, and coarse final vibrations including the opening sound of the mitral valve).

(6) Interval between the beginning of the auricular sound and the beginning of the first sound (a-I).

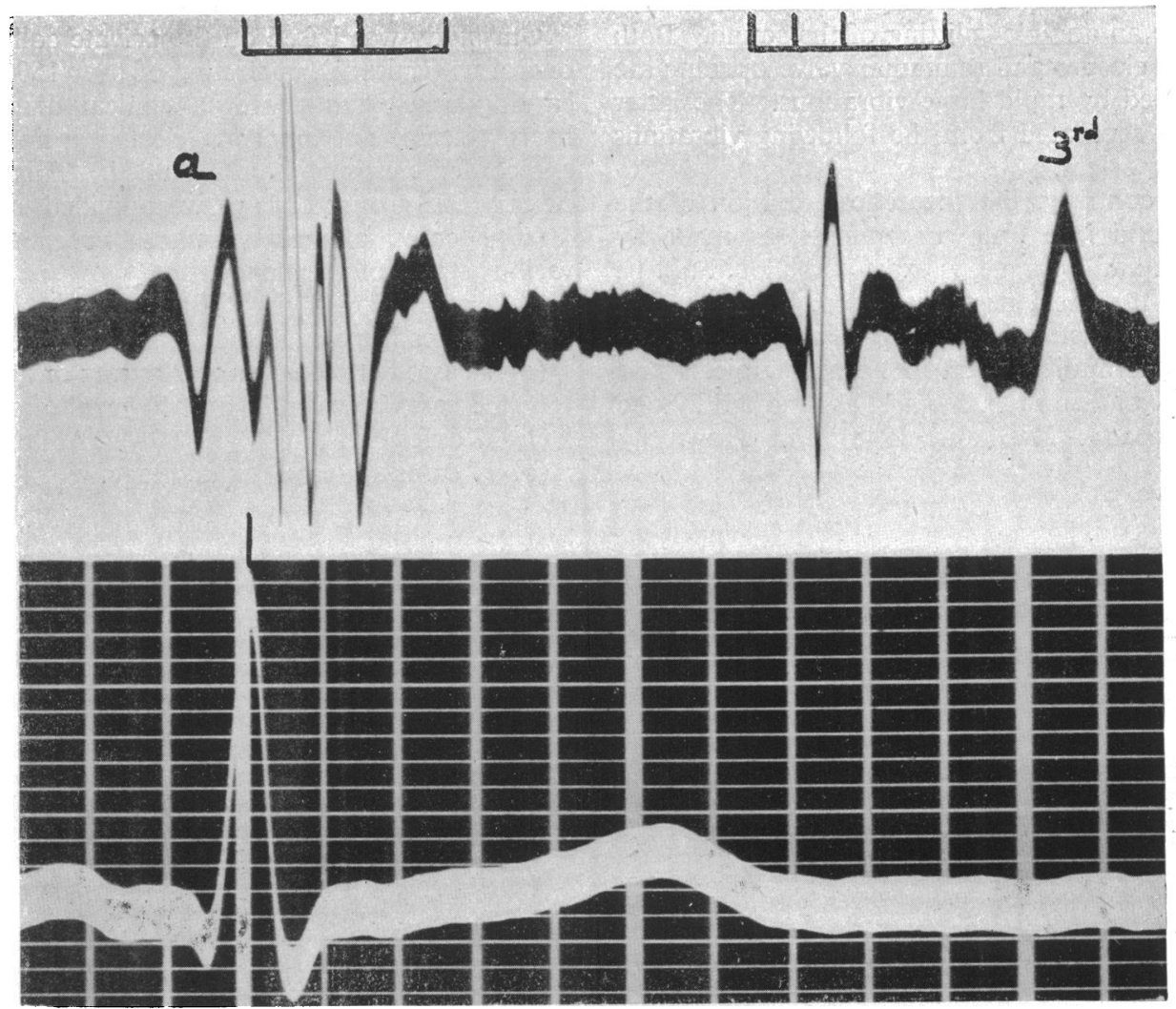

FIG. 3.-Phonocardiogram of a boy of 15 years. Loud auricular sound very close to the first sound; third sound. In this case, an arbitrary setting of the beginning of the first sound at the peak of $R$ wave of the electrocardiogram would have been necessary as no clearcut division exists between auricular and first sounds.

* In the adults, a funnel having $5 \mathrm{~cm}$. of diameter was used; in children, a smaller funnel having a diameter of $3.7 \mathrm{~cm}$. was preferred.

$\uparrow$ In a few cases, it was noted that the auricular sound gave vibrations lasting up to the beginning of the phase of large vibrations of the first sound. In others, no vibration of a coarse type preceded this phase. In order to obtain a clear-cut point in such cases, the peak of the $R$ wave of the electrocardiogram was taken as the initiation of the first sound as an arbitrary and practical reference which may entail a slight error. 


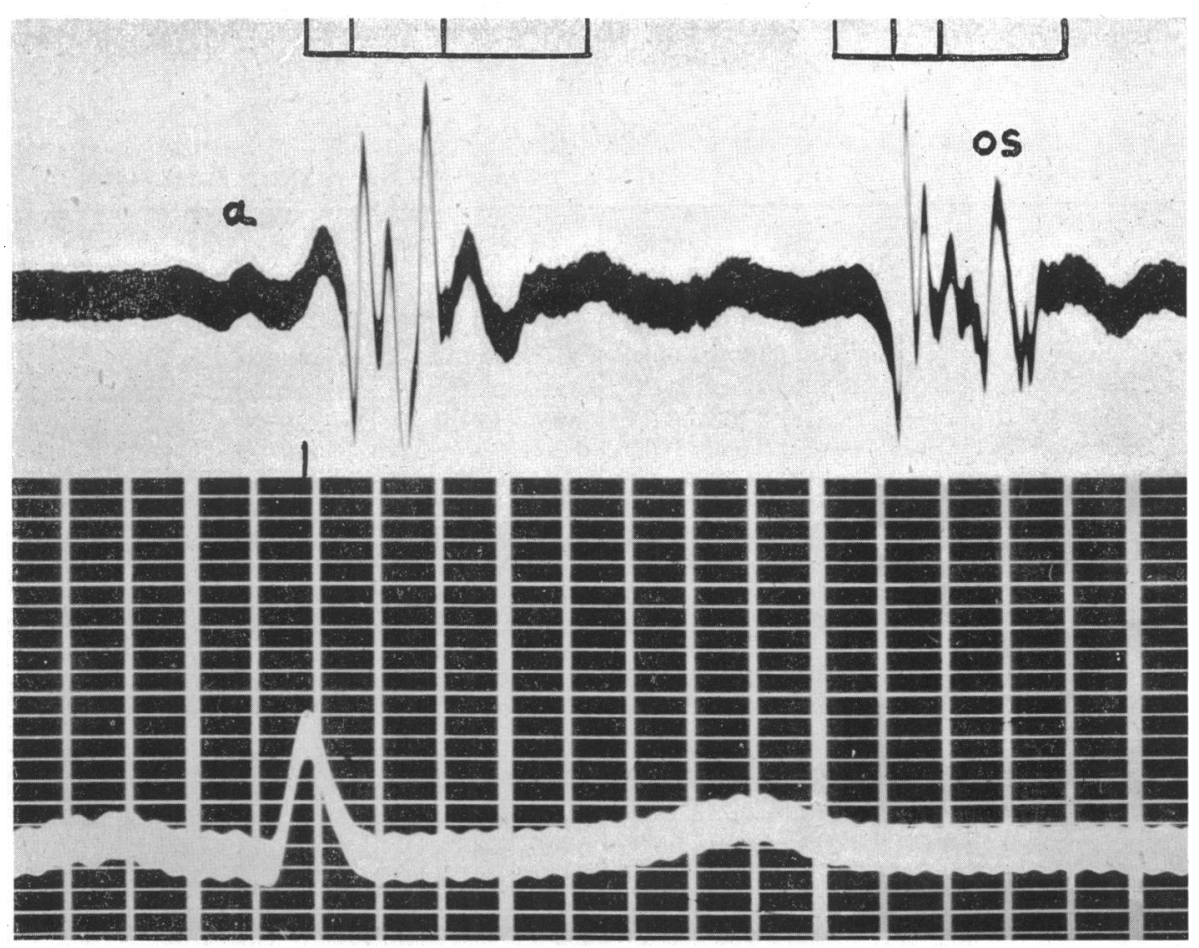

FIG. 4.-Phonocardiogram of a normal woman of 33 years. Two higher vibrations are present in phase 2 of the first sound. The second sound includes a high vibration (os) at the opening of the mitral valve.

The subject has been followed for eight years since this tracing and repeated phonocardiograms recorded. No heart disease was ever recognized. Subsequent tracings indicated a more conventional aspect of the second sound.

(7) Interval between the peak of the largest oscillation of the second sound and the beginning of the third sound (II-III).

The results of the study are reported in the following tables. Occasional small differences occur between the average figure of the total duration of the first or second sound and the average sum of the three phases of each. This is due to the fact that the first phase was measured only in a percentage of cases (indicated in parenthesis) while in others, with no visible vibration occurring in that phase, no measurement was possible.

A summary of the protocols of our observations is given here. Table IV shows the average duration of the heart sounds and their phases and Table $V$ indicates the extreme variations of these sounds.

The average length of the first sound above the age of 10 was found to be 0.146 sec. at the apex and $0 \cdot 140$ sec. at the aortic area.

The average length of the second sound in the same conditions was found to be 0.097 and 0.104 sec., respectively. That of the third sound was found to be 0.059 and $0.042 \mathrm{sec}$.

The average interval separating the beginning of the auricular sound from that of the first sound was found to be $0.058 \mathrm{sec}$. for both areas; while that separating the main oscillation of the second sound from the beginning of the third, $0.15 \mathrm{sec}$. at the apex and $0.17 \mathrm{sec}$. at the aortic area.*

The extreme variations of the first and second sounds are indicated in Table $V$. Between the ages of 11 and 20, the first sound varied from $0 \cdot 12$ to $0.16 \mathrm{sec}$. at the apex and from 0.11 to 0.16 at the aortic area; and the second sound, from 0.08 to $0 \cdot 18 \mathrm{sec}$. at both areas.

Between the ages of 41 and 60 , the first sound varied from 0.07 to $0.22 \mathrm{sec}$. at the apex and from 0.09 to $0.22 \mathrm{sec}$. at the aortic area; and the second sound, from 0.05 to 0.16 and from 0.06 to 0.14 sec.; respectively.

* The latter figure was obtained on a small percentage of the cases ( 9 per cent). 
TABLE IV

Average Duration of the Heart Sounds, their Phases and their Intervals *

\begin{tabular}{|c|c|c|c|c|c|c|c|c|c|c|c|c|c|}
\hline & & & & First Sou & und (sec & & & cond so & und (sec & & & & \\
\hline Age gro & oups (y & ears) & Total & $\begin{array}{c}\text { 1st } \\
\text { phase }\end{array}$ & $\begin{array}{c}\text { 2nd } \\
\text { phase }\end{array}$ & $\begin{array}{c}\text { 3rd } \\
\text { phase }\end{array}$ & Total & $\begin{array}{c}\text { 1st } \\
\text { phase }\end{array}$ & $\begin{array}{c}\text { 2nd } \\
\text { phase }\end{array}$ & $\begin{array}{c}\text { 3rd } \\
\text { phase }\end{array}$ & $\begin{array}{c}\text { III } \\
\text { sound } \\
\text { (sec.) }\end{array}$ & $\begin{array}{c}\mathrm{a}-\mathrm{I} \\
(\mathrm{sec} .)\end{array}$ & $\begin{array}{l}\text { II-III } \\
\text { (sec.) }\end{array}$ \\
\hline $\begin{array}{l}\text { Fotal sounds } \\
\text { Below } 4\end{array}$ & ls & \begin{tabular}{ll|}
. &.. \\
.. &.. \\
\end{tabular} & \begin{tabular}{|l|}
0.085 \\
0.070 \\
\end{tabular} & $\begin{array}{c}0.010 \\
-\end{array}$ & $\begin{array}{l}0.025 \\
0.040 \\
\end{array}$ & \begin{tabular}{l|}
0.055 \\
0.030 \\
\end{tabular} & \begin{tabular}{l|}
0.055 \\
0.060 \\
\end{tabular} & $\begin{array}{c}0.010 \\
-\end{array}$ & \begin{tabular}{l|}
0.027 \\
0.020 \\
\end{tabular} & \begin{tabular}{l|}
0.020 \\
0.040 \\
\end{tabular} & 二 & E & E \\
\hline $4-10$ & 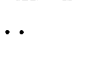 & .. & $\begin{array}{l}0.120 \\
0.145\end{array}$ & 0.020 & \begin{tabular}{l|}
0.040 \\
0.070
\end{tabular} & \begin{tabular}{l|}
0.080 \\
0.065
\end{tabular} & $\begin{array}{l}0.065 \\
0.110\end{array}$ & $0 . \overline{010}$ & \begin{tabular}{l|}
0.015 \\
0.055
\end{tabular} & $\begin{array}{l}0.050 \\
0.050\end{array}$ & $\begin{array}{l}0.050 \\
0.040\end{array}$ & $\begin{array}{l}0.060 \\
0.060\end{array}$ & $\begin{array}{l}0.12 \\
0.14\end{array}$ \\
\hline $11-20$ & 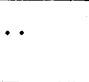 & .. & $\begin{array}{l}0.147 \\
0.147\end{array}$ & $\begin{array}{l}0.016 \\
0.010\end{array}$ & $\begin{array}{l}0.069 \\
0.064\end{array}$ & \begin{tabular}{l|}
0.071 \\
0.066
\end{tabular} & $\begin{array}{l}0.097 \\
0.120\end{array}$ & $\begin{array}{l}0.018 \\
0.020\end{array}$ & $\begin{array}{l}0.015 \\
0.034\end{array}$ & $\begin{array}{l}0.056 \\
0.056\end{array}$ & $\begin{array}{c}0.050 \\
-\end{array}$ & $\begin{array}{l}0.060 \\
0.055\end{array}$ & $\begin{array}{c}0.14 \\
-\end{array}$ \\
\hline $21-40$ & 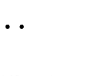 & . & $\begin{array}{l}0.146 \\
0.145\end{array}$ & $\begin{array}{l}0.020 \\
0.020\end{array}$ & $\begin{array}{l}0.063 \\
0.060\end{array}$ & \begin{tabular}{|l|}
0.078 \\
0.071
\end{tabular} & $\begin{array}{l}0 \cdot 107 \\
0 \cdot 114\end{array}$ & $\begin{array}{l}0.020 \\
0.018\end{array}$ & $\begin{array}{l}0.028 \\
0.043\end{array}$ & $\begin{array}{l}0.069 \\
0.055\end{array}$ & $\begin{array}{l}0.061 \\
0.043\end{array}$ & $\begin{array}{l}0.064 \\
0.072\end{array}$ & $\begin{array}{l}0 \cdot 16 \\
0 \cdot 18\end{array}$ \\
\hline $41-60$ & & & \begin{tabular}{l|}
$0 \cdot 149$ \\
$0 \cdot 144$
\end{tabular} & $\begin{array}{l}0.020 \\
0.020\end{array}$ & $\begin{array}{l}0.057 \\
0.064\end{array}$ & $\begin{array}{l}0.080 \\
0.068\end{array}$ & \begin{tabular}{l|}
0.097 \\
0.098
\end{tabular} & $\begin{array}{l}0.016 \\
0.013\end{array}$ & $\begin{array}{l}0.024 \\
0.040\end{array}$ & \begin{tabular}{l|}
0.068 \\
0.053
\end{tabular} & $\begin{array}{l}0.057 \\
0.040\end{array}$ & $\begin{array}{l}0.061 \\
0.052\end{array}$ & $\begin{array}{l}0.18 \\
0.19\end{array}$ \\
\hline Above 60 & 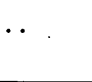 & & \begin{tabular}{l|l|}
$0 \cdot 141$ \\
$0 \cdot 123$
\end{tabular} & $\begin{array}{l}0.024 \\
0.023\end{array}$ & $\begin{array}{l}0.050 \\
0.063\end{array}$ & $\begin{array}{l}0.080 \\
0.054\end{array}$ & \begin{tabular}{l|}
0.087 \\
0.085
\end{tabular} & $\begin{array}{l}0.020 \\
0.010\end{array}$ & \begin{tabular}{l|}
0.025 \\
0.038
\end{tabular} & $\begin{array}{l}0.053 \\
0.044\end{array}$ & - & $\begin{array}{l}0.050 \\
0.060\end{array}$ & - \\
\hline $\begin{array}{l}\text { Overall ave } \\
\text { above } 10\end{array}$ & $\begin{array}{l}\text { rages } \\
\text { years }\end{array}$ & $\begin{array}{l}\text { for ages } \\
\text {.. }\end{array}$ & $\begin{array}{l}0 \cdot 146 \\
0 \cdot \overline{140}\end{array}$ & \begin{tabular}{l|}
0.020 \\
$(46 \%)$ \\
0.020 \\
$(55 \%)$
\end{tabular} & $\begin{array}{l}0.060 \\
0 . \overline{0}\end{array}$ & $\begin{array}{l}0.077 \\
0 . \overline{06}\end{array}$ & $\begin{array}{c}0.097 \\
0 . \overline{104} \\
-\end{array}$ & \begin{tabular}{|l|}
0.018 \\
$(46 \%)$ \\
0.015 \\
$(38 \%)$
\end{tabular} & $\begin{array}{l}0.023 \\
0 . \overline{039}\end{array}$ & $\begin{array}{l}0.061 \\
0.052\end{array}$ & $\begin{array}{c}0.059 \\
(50 \%) \\
0.042 \\
(9 \%)\end{array}$ & $\begin{array}{c}0.058 \\
(78 \%) \\
0.058 \\
(45 \%)\end{array}$ & $\begin{array}{c}0.15 \\
(50 \%) \\
0.17 \\
(9 \%)\end{array}$ \\
\hline
\end{tabular}

* Note: The top figures refer to measurements at the apex; the figures below are those from the aortic area.

TABLE V

Extreme Variations of the Heart Sounds and their Main Phases

\begin{tabular}{|c|c|c|c|c|c|c|c|c|}
\hline \multirow[b]{3}{*}{ Ages } & \multicolumn{4}{|c|}{ First sound } & \multicolumn{4}{|c|}{ Second sound } \\
\hline & \multicolumn{2}{|c|}{ Maximum (sec.) } & \multicolumn{2}{|c|}{ Minimum (sec.) } & \multicolumn{2}{|c|}{ Maximum (sec.) } & \multicolumn{2}{|c|}{ Minimum (sec.) } \\
\hline & $\begin{array}{c}\text { Total } \\
\text { duration }\end{array}$ & 2nd Phase & $\begin{array}{c}\text { Total } \\
\text { duration }\end{array}$ & 2nd phase & $\begin{array}{c}\text { Total } \\
\text { duration }\end{array}$ & 2nd phase & $\begin{array}{c}\text { Total } \\
\text { duration }\end{array}$ & 2nd phase \\
\hline \multicolumn{9}{|c|}{$A P E X$} \\
\hline $\begin{array}{l}11-20 \\
21-40 \\
41-60\end{array}$ & $\begin{array}{l}0 \cdot 16 \\
0 \cdot 22 \\
0 \cdot 22\end{array}$ & $\begin{array}{l}0 \cdot 12 \\
0 \cdot 10 \\
0 \cdot 10\end{array}$ & $\begin{array}{l}0.12 \\
0.09 \\
0.07\end{array}$ & $\mid \begin{array}{l}0.04 \\
0.02 \\
0.03\end{array}$ & $\begin{array}{l}0.12 \\
0 \cdot 18 \\
0 \cdot 16\end{array}$ & $\begin{array}{l}0.04 \\
0.08 \\
0.05\end{array}$ & $\begin{array}{l}0.08 \\
0.04 \\
0.05\end{array}$ & $\begin{array}{l}0.01 \\
0.01 \\
0.01\end{array}$ \\
\hline \multicolumn{9}{|c|}{ AORTIC AREA } \\
\hline $\begin{array}{l}11-20 \\
21-40 \\
41-60\end{array}$ & $\begin{array}{l}0 \cdot 16 \\
0 \cdot 22 \\
0 \cdot 20\end{array}$ & $\begin{array}{l}0.08 \\
0.10 \\
0.09\end{array}$ & $\begin{array}{l}0 \cdot 11 \\
0 \cdot 10 \\
0 \cdot 09\end{array}$ & $\begin{array}{l}0.06 \\
0.03 \\
0.04\end{array}$ & $\begin{array}{l}0.12 \\
0.16 \\
0.14\end{array}$ & $\begin{array}{l}0.04 \\
0.10 \\
0.06\end{array}$ & $\begin{array}{l}0.08 \\
0.08 \\
0.06\end{array}$ & $\begin{array}{l}0.03 \\
0.03 \\
0.02\end{array}$ \\
\hline
\end{tabular}


At the apex, the maximum duration of the second phase, that of the large oscillations, was found to be $0.12 \mathrm{sec}$. for the first sound and $0.04 \mathrm{sec}$. for the second sound in the younger age group; 0.10 and 0.08 sec., respectively, for the group between 21 and $40 ;$ and 0.10 and $0.05 \mathrm{sec}$. for the older age group. At the aortic area, these same oscillations measured 0.08 and $0.04 \mathrm{sec}$. for the first group; $0 \cdot 10 \mathrm{sec}$. for both sounds, for the second age group; and 0.09 and 0.06 , for the group between 41 and 60 .

On the other hand, the average duration of this phase was found to be $0.06 \mathrm{sec}$. for the first sound and $0.023 \mathrm{sec}$. for the second, at the apex; and 0.063 and 0.039 sec., respectively, at the aortic area.

\section{Discussion}

A comparison of our data with those of Rappaport and Sprague $(1941,1942)$ shows that our figures were found to be longer for both sounds and also for maxima and minima. This may be explained partly by the larger number of subjects studied and partly by the different way of measuring the sounds which, in our case, is illustrated by Fig. 1.

We believe that breaking the sounds into three phases provides an easier and more rapid method of determining the length of the most important phase, that of large oscillations, which are chiefly connected with valvular events of the heart.*

As a study of the protocols will show, a total duration of the sounds (chiefly of the first sound) that far exceeds the average is found in only a few stray cases. This total duration is increased because

* Whenever an accurate break-down of the sounds into their components is necessary because the phonocardiogram is used as a time reference for other tracings (cardiogram, phlebogram, pneumocardiogram, or fluorocardiogram), the division should follow the lines previously indicated by Orias and Braun Menendez and by Rappaport and Sprague with the slight modification indicated in Table II for the first sound complex. the third phase, mainly due to coarse vascular vibrations, is longer than average. This observation increases the importance of separately measuring the three phases of each sound.

\section{Summary AND CoNClusions}

The authors have studied the duration of the heart sounds and their intervals in a series of phonocardiograms recorded in 185 normal subjects, making use of a stethoscopic microphone.

The difficulty in the measurement of the normal heart sounds led the authors to propose a new practical division of these in the phonocardiogram for general clinical work. Both the first and the second sounds are divided into three phases-the first phase of small and slow vibrations, the second of high and rapid vibrations, and the third of small and slow vibrations.

A sound should be considered abnormal not only when its total duration is prolonged but also when the duration of the phase of large vibrations is beyond the maximum normal duration of that phase.

For each of the various age groups, total duration and partial durations of the sounds were measured by the authors. Maximum and minimum and average figures are given. The intervals between auricular sound and first sound, and those between the second and third sounds are also studied in the various age groups.

\section{REFERENCES}

Luisada, A. A. (1943). Arch. Ped., 60, 498. (1948). Heart: A Physiological and Clinical Study of Cardiovascular Diseases. Williams and Wilkins, Baltimore.

Orias, O., and Braun Menendez, E. (1939). The Heart Sounds in Normal and Pathological Conditions. Oxford Univ. Press, London and New York.

Rappaport, M. B., and Sprague, H. B. (1941). Amer. Heart J., 21, 257.

-, - (1942). Ibid., 23, 591. 